\title{
Supratentorial Meningioma
}

National Cancer Institute

\section{Source}

National Cancer Institute. Supratentorial Meningioma. NCI Thesaurus. Code C7048.

A mening ioma that affects the supratentorial brain. 